\title{
Chlorine isotopes of salts xenoliths from Udachnaya-East kimberlite pipe (Russia)
}

\author{
Alexander G. Polozov ${ }^{1,2}$, Henrik Svensen ${ }^{2}$, Sverre Planke ${ }^{2,3}$ \\ ${ }^{1}$ Institute of Geology of Ore Deposits RAS, Moscow, Russia, \\ ${ }^{2}$ Physics of Geological Processes, University of Oslo, Norway, \\ ${ }^{3}$ Volcanic Basin Petroleum Research, Oslo, Norway
}

\section{Introduction and geological setting}

Rock salt are spectacular components of the Udachnaya-East kimberlite, and has attracted considerable attention (Kamenetsky et al., 2004, 2006; 2007a, b; Maas et al., 2005; Golovin et al., 2007; Sharygin et al., 2007a, b). In this volume (Polozov et al.) we present new data on the geological occurrence of the kimberlite-hosted rock salt, the mineral content and the chlorine isotope composition of the halides. We show that the rock salt represents xenoliths from the surrounding Cambrian evaporite rocks that underwent thermal metamorphism and local melting after emplacement in the kimberlite melt.

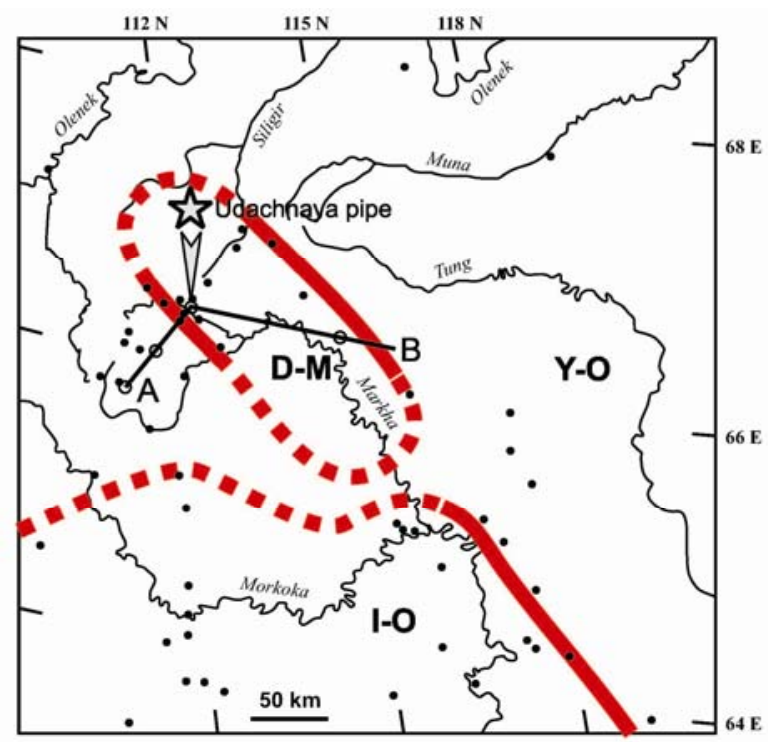

Irkutsk - Olekma (I-O) carbonate platform and Daldyn - Markha (D-M) carbonate bank conjugated with Yudom-Olenek (Y-O) basin at Late Amga (Middle Cambrian) Time. Reef margins established (solid line) and proposed (dotted line) compiled from Sukhov (2001) and Kononov et al. (2007). Dots are prospecting boreholes and A-B line is the cross-section. Geological setting of Udachnaya kimberlite pipe presented in the other contribution (Polozov et al., this volume).

\section{Sampling and analytical approach}

XRD analyses show that the xenoliths are dominated by halite with minor amounts of sylvine, calcite, and clay minerals. We have analyzed the chlorine isotope composition of six Udachnaya pipe halite samples. Core and rim samples were analyzed from two of the xenoliths. The resulting $\delta^{37} \mathrm{Cl}$ values fall into the evaporite range ( +0.47 to $-0.43 \%$ o), in agreement with published evaporite data (Sharp et al., 2007). For the individual xenoliths, the $\delta^{37} \mathrm{Cl}$ values decrease from core to rim.

\section{U-9793}
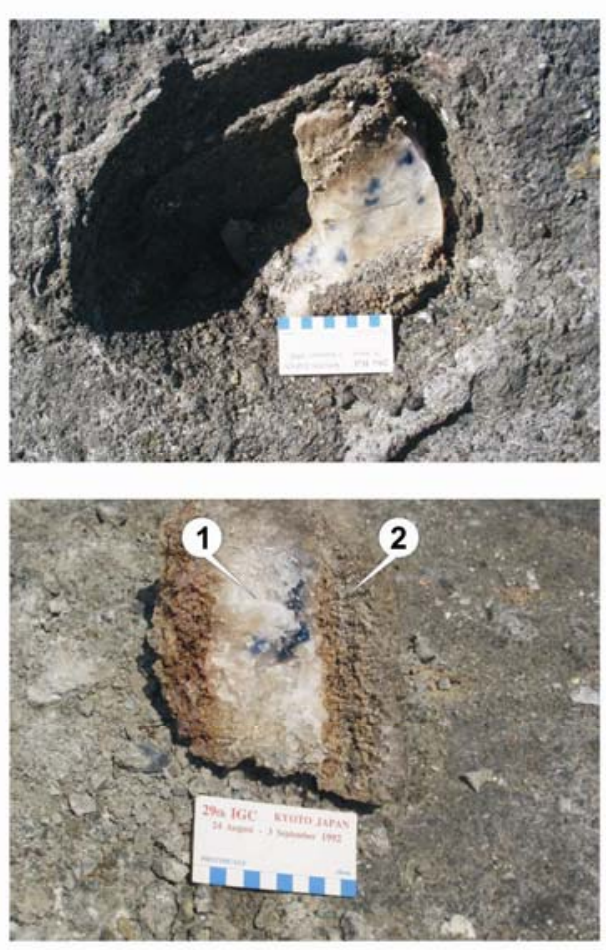


\section{U-9812}
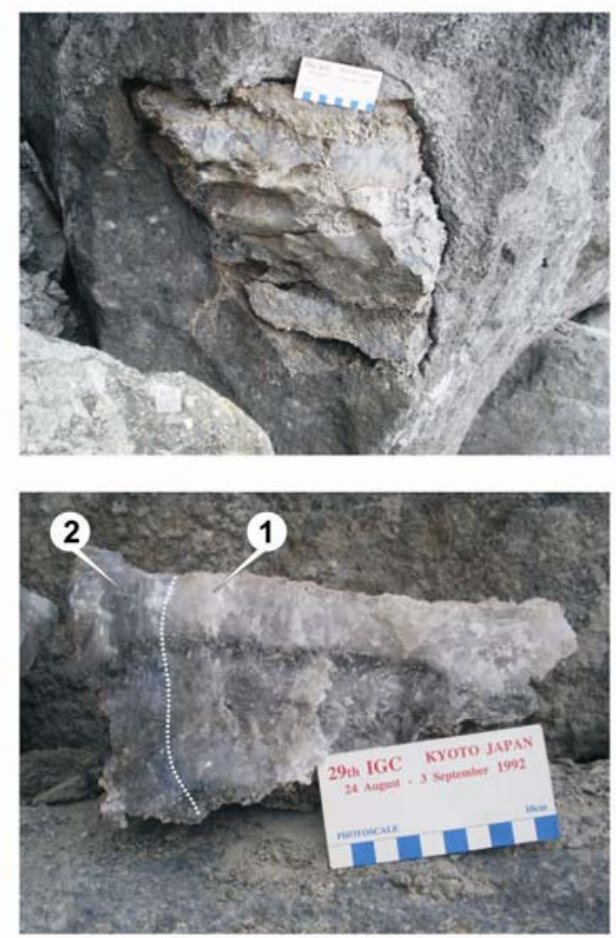

Salt xenoliths composed mainly by salts with minor other minerals. Xenoliths demonstrate visibly different compositions at core and rims. These parts were studied separately with using XRD, EPMA and chlorine isotopes.

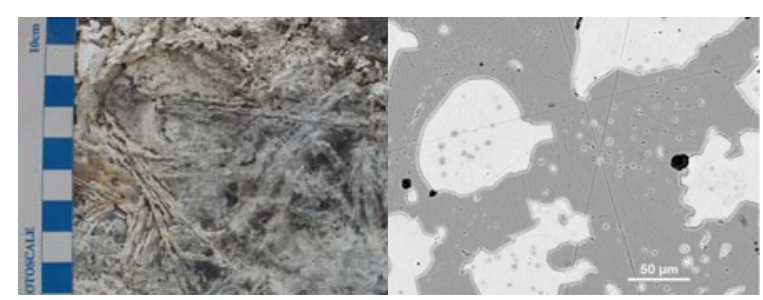

Complex intergrowing between sylvite and halite were revealed in salts from carbonate-halide xenoliths by EPMA, however, its chlorine isotopes fall into interval of sedimentary salts.

\section{Conclusion}

Our results demonstrate a sedimentary origin of salts from Udachnaya-East pipe. We speculate that the isotope depletion along the xenolith rims is due to diffusion processes. The results are important for understanding the geochemical cycle of chlorine, as the suggestion that the kimberlite salt $\delta^{37} \mathrm{Cl}$ represents mantle $\delta^{37} \mathrm{Cl}$ (Sharp et al., 2007) can be discarded.

\section{References}

Golovin, A. N., Sharygin, V. V. and Pokhilenko, N. P. 2007. Melt Inclusions in Olivine Phenocrysts in Unaltered Kimberlites from the Udachnaya-East Pipe, Yakutia: Some Aspects of Kimberlite Magma Evolution during Late Crystallization Stages. Petrology, 15, 168-183.

Kamenetsky, M. B., Sobolev, A. V., Kamenetsky, V. S., Maas, R., Danyushevsky, L. V., Thomas, R., Pokhilenko, N. P. and Sobolev, N. V., 2004. Kimberlite melts rich in alkali chlorides and carbonates: A potent metasomatic agent in the mantle. Geology, 32, 845-848.

Kamenetsky, V. S., Kamenetskaya, M. B., Sharygin, V. V. and Golovin, A. N. 2007b. Carbonate-chloride enrichment in fresh kimberlites of the UdachnayaEast pipe, Siberia: A clue to physical properties of kimberlite magmas? Geophysical Research Letter, 343, L09316.

Kamenetsky, V. S., Kamenetskaya, M. B., Sharygin, V. V., Faure, K. and Golovin, A. N. 2007a. Chloride and carbonate immiscible liquids at the closure of the kimberlite magma evolution (Udachnaya-East kimberlite, Siberia). Chemical Geology, 237, 384400.

Kamenetsky, V. S., Sharygin, V. V., Kamenetskaya, M. B. and Golovin, A. N. 2006. Chloride-Carbonate Nodules in Kimberlites from the Udachnaya Pipe: Alternative Approach to the Evolution of Kimberlite Magmas. Geochemistry International, 44, 935-940.

Maas, R., Kamenetsky, M. B., Sobolev, A. V., Kamenetsky, V. S. and Sobolev, N. V., 2005. Sr, Nd, and Pb isotope evidence for a mantle origin of alkali chlorides and carbonates in the Udachnaya kimberlite, Siberia. Geology, 33, 549-552.

Sharp, Z. D., Barnes, J. D., Brearley, A. J., Chaussidon, M. T., Fischer, P. and Kamenetsky, V. S. 2007. Chlorine isotope homogeneity of the mantle, crust and carbonaceous chondrites. Nature, 446, 10621065.

Sharygin, V. V., Golovin, A. N., Pokhilenko, N. P. and Kamenetsky, V. S., 2007b. Djerfisherite in the Udachnaya-East pipe kimberlites (SakhaYakutia,Russia): paragenesis, composition and origin. European Journal of Mineralogy, 19, 51-63.

Sharygin, V. V., Kamenetsky, V. S., Kamenetskaya, M. B., Seretkin, Yu. V. and Pokhilenko, N. P. 2007a. Rasvumite from the Udachnaya-East Pipe: The First Finding in Kimberlites. Doklady Earth Sciences, 415A, 929-934. 